J. Clin. Chem. Clin. Biochem.

Vol. 19, 1981, pp. 961-965 \title{
Interlaboratory Investigation on the CEA Assay (Roche) with Column Filtration, Dialysis and
Ultrafiltration Techniques
}

$\left.\mathrm{By}^{1}\right)$ H. Carmann

F. Hoffmann-La Roche \& Co..Ltd, Dept. Diagnostica, Schweizerhalle, Switzerland,

A. van Dalen

Bleuland Ziekènhuis, Gouda, The Netherlands,

E. J. van Kampen

Diakonessenhuis, Groningen, The Netherlands,

H. Keogh

Bioscientia, Mainz, Federal Republic of Germany,

E. Lüdin

F. Hoffmann-La Roche \& Co. Ltd, EDP./ Technical and Scientific Systems Development, Basle, Switzerland,

\section{H. Orjasaeter}

Statens Institut for Folkehelse, Immunologisk Avdeling, Oslo 1, Norway,

P. van der Ploeg

Diakonessenhuis, Groningen, The Netherlands and

\section{H. J. Staab}

Friedrich Miescher Laboratorium, Max Planck Gesellschaft, Tübingen, Federal Republic of Germany

(Received November 11, 1980/March 27, 1981)

Summary: An interlaboratory study on the reproducibility of the CEA 〈Roche〉 RIA Test was carried out. Four different plasma pools of approximately $2,3,6$, and $12 \mu \mathrm{g} / 1$ CEA were tested over a period of 4 weeks with 4 different lots of reagents in order to determine the interassay variances. At the same time we compared the lately introduced column technique with the dialysis and ultrafiltration method. Best results were obtained with the column technique which also showed best reproducibility. Only $1.4 \%$ of samples showed deviations $>5 \%$ between the mean of CEA duplicates and single CEA values, and these were omitted from the evaluation. On the other hand about $15 \%$ of the correspondding dialysis results showed deviations $>5 \%$ and were excluded from the evaluation. The methods compared showed a good correlation with a coefficent of 0.96 , but the average values for the CEA determination, using the columns technique were lower than those obtained from dialysis. Interassay variances were greater for the dialysis procedures, i.e. $1.88 \pm 0: 81,3.25 \pm 0.83,5.81 \pm 1.09$, and $11-91 \pm 1.23$ compared with $1.77 \pm 0.54,2.63 \pm 0.68,4.89 \pm 0.79$, and $11.16 \pm 1.23$ for the column technique. There were no systematic changes of the CEA values over the period of 4 weeks, thus giving optimal conditions for a follow up of patients.

Ringversuche mit dem CEA Test (Roche) unter Anwendung von Gelfiltrations-, Dialyse- und Ultrafiltrationstechniken

Zusammenfassung: Ein Ringversuch über die Reproduzierbarkeit des CEA (Roche) RIA Tests wurde durchgefürt. Vier verschiedene Blutplasmen mit etwa 2, 3, 6 und $12 \mu \mathrm{g} / 1 \mathrm{CEA}$ wurden während 4 Wochen mit 4 verschiedenen Reagenzienchargen untersucht, um die Varianz von Bestimmung zu Bestimmung festzustellen. Gleichzeitig wurde

1) The authors are alphabetically arranged. 
die kürzlich eingeführte Gelfiltrationsmethode mit der Dialyse- bzw. Ultrafiltrationstechnik verglichen. Die besten Ergebnisse wurden mit der Gelfiltrationsmethode erzielt, die auch die höchste Reproduzierbarkeit zeigte. Mit dieser Methode wiesen nur 1,4\% der Proben Abweichungen von 5\% des Mittelwertes der Doppelbestimmungen zur CEAEinfachbestimmung auf und mußten daher von der Auswertung ausgeschlossen werden. Die verglichenen Methoden korrelierten mit einem Korrelationskoeffizienten von 0,96 gut miteinander. Im Durchschnitt jedoch ergaben CEABestimmungen mit der Gelfiltrationsmethode niedrigere Werte als die anderen Methoden. Die Varianz von Bestimmung zu Bestimmung war für die Dialysemethode mit 1,88 $\pm 0,81,3,25 \pm 0,83,5,81 \pm 1,09$ und 11,91 $\pm 1,23$ größer als die korrespondierenden Werte für die Gelfiltrationsmethode mit $1,77 \pm 0,54,2,63 \pm 0,68,4,89 \pm 0,79$ und $11,16 \pm 1,23$. Es wurden keine systematischen Veränderungen der CEA-Werte über eine Periode von 4 Wochen gefunden. Daraus ergeben sich optimale Verhältnisse für eine Verlaufskontrolle bei Patienten.

\section{Introduction}

The diagnosis of a carcinoma and the follow up carcinoma patients is still a very intriguing problem. Any new laboratory parameter, that could possibly serve for the detection of carcinoma, is therefore eagerly awaited by clinicians. Consequently, such new diagnostic tools always bear the danger of failure, due to insufficient knowledge of all the variables involved.

This danger has also threatened the determination of CEA in carcinoma patients from the beginning. The upper limits taken as normal CEA plasma values varied from 2 to more than $10 \mu \mathrm{g} / \mathrm{l}$, depending on the antisera and assay procedures used in the different assays (1-4). The hazards of misinterpretation of CEA results are evident, especially in follow up studies. This requires that the assay and procedures for determination of the CEA are clearly specified. A change of the CEA assay must be avoided as far as possible. A switch from one laboratory to another often produces confusing CEA results, even with the same reagents and the same assay procedures (5).

To elucidate the reliability of the CEA determination with the CEA determination with the CEA 〈Roche〉 RIA Test kit, an international study group was set up, comprising 6 laboratories which had performed CEA determinations with close quality control for years. The aim of this joint study was mainly to compare the time saving column method introduced recently with that of dialysis and ultrafiltration, with respect to both the level of measurement and the reproductibility of the methods.

\section{Experimental}

Material

In a common protocol, agreed by all participants, 4 plasma pools with different CEA concentrations of about $2 \mu \mathrm{g} / 1$ for pool 1 , $3 \mu \mathrm{g} / 1$ for pool $2,6 \mu \mathrm{g} / 1$ for pool 3 , and $12 \mu \mathrm{g} / 1$ for pool 4 were prepared by F. Hoffmann-La Roche \& Co. Each plasma was separately prepared and contained at least 20 individual patient plasmas. The plasmas were sent deep frozen $\left(-60^{\circ} \mathrm{C}\right)$ to each participating laboratory.

To check for laboratory errors, the 4 control specimens packed with the (Roche) test kit were also included in the protocol. These specimens are made of a human plasma pool with no measurable CEA level and supplemented with CEA prepared from human liver metastases. The performance range given by the manufacturer was $1.8,5.5,8.5$, and $14.5 \mu \mathrm{g} / \mathrm{l}$, resp.

The comparative study between Sephadex columns and dialysis or ultrafiltration (for one of the laboratories) was performed within 4 weeks according to the following scheme: 3 duplicates of each of the 4 plasma pools and 1 duplicate of the 4 control specimens (kit components) had to be analyżed per week. Each laboratory received weekly a freshly prepared CEA (Roche) RIA Test kit and 40 columns of one Lot.

\section{Methods}

\section{Dialysis}

$0.5 \mathrm{ml}$ of pool plasma or control specimen was mixed with $2.0 \mathrm{ml}$ of $\mathrm{NaCl}$ solution, $9 \mathrm{~g} / \mathrm{l}$, followed by $2.5 \mathrm{ml}$ of perchloric acid $\left(\mathrm{HClO}_{4}\right.$, p.a.) $1.2 \mathrm{~mol} / 1,4^{\circ} \mathrm{C}$. This solution was fully mixed by vortexing for $10 \mathrm{~s}$, then centrifuged $20 \mathrm{~min}$ at $1000 \mathrm{~g}$. The supernatant was placed in dialysis bags and dialysed 4 times for 3 hours against distilled water (conductivity $<1 \mu \mathrm{S} \mathrm{cm}^{-1}$; volume: at least 50 times that of the dialysis bags). The bags were finally dialysed at least 3 hours (maximum 18 hours) against $0.01 \mathrm{~mol} / 1$ of ammonium acetate, $\mathrm{pH} 6.5 \pm 0.2$ (volume: 50 times the volume of the dialysis bags).

\section{Ultrafiltration}

The Amicon MC-40 system adapted with ultrafiltration membranes type CM 200 was used. The perchloric acid extracts of plasmas (see dialysis) were neutralized with approximately $1.2 \mathrm{ml}$ of $3 \mathrm{~mol} / 1$ Tris to $\mathrm{pH} \mathrm{7.1} \pm 0.1$. The ultrafiltration was performed as described in the operating instructions provided with the instrument. The extracted CEA was retained after ultrafiltration on the CM 200 filters. It was then dissolved in $5 \mathrm{ml}$ of water and again ultrafiltered to dryness. This step was repeated once, and the retained CEA was finally dissolved in $5 \mathrm{ml}$ of ammonium acetate buffer $0.01 \mathrm{~mol} / 1, \mathrm{pH} 6.5 \pm 0.2$, and tested in the radioimmunoassay.

\section{Column purification}

The columns contained Sephadex G 50 gel in ammonium acetate $0.01 \mathrm{~mol} / \mathrm{l}$ and were ready for use. The buffer solution flowing out after cutting the plastic tips and removing the protective seal was discarded. The perchioric acid extracts of plasmas (see dialysis) were decanted into the columns. The buffer solution flowing out at this step was also discarded. CEA was then eluted from the column with $6.5 \mathrm{ml}$ of ammonium acetate $0.01 \mathrm{~mol} / \mathrm{l}$, $\mathrm{pH} 6.7 \pm 0.2$ and tested in the radioimmunoassay.

\section{Radioimmunoassay}

The CEA plasma samples, together with the CEA standards in EDTA buffer (from the test kit) were incubated with goat antiCEA serum for 30 min at $45^{\circ} \mathrm{C}$. After the addition of $\left[{ }^{125} \mathrm{I}\right.$. $\mathrm{CEA}$, a second incubation was performed at $45^{\circ} \mathrm{C}$ for $30 \mathrm{~min}$. The CEA immune complexes were then trapped in zirconyl phosphate gel, washed, and the retained radioactivity measured. CEA concentrations were calculated from the standard curve. 


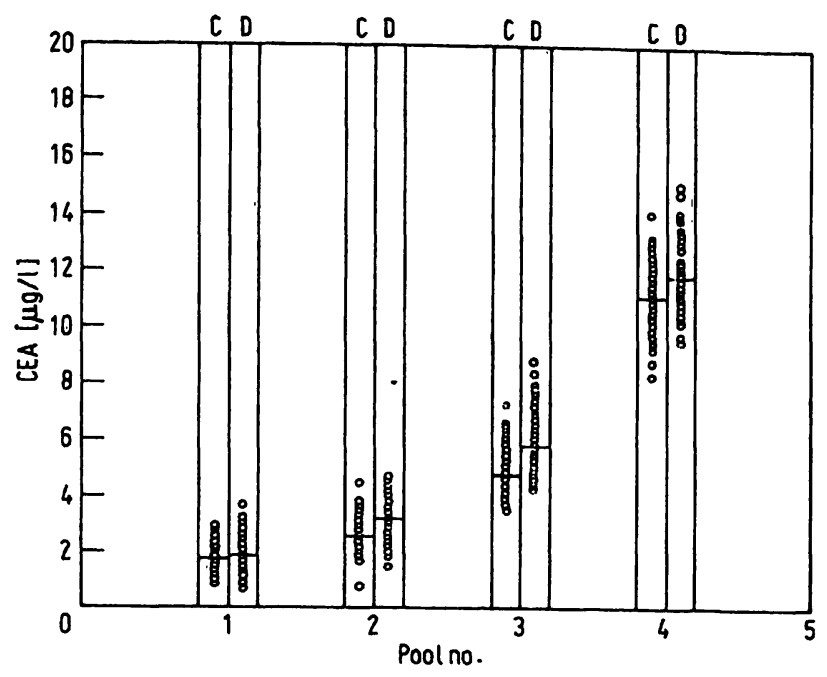

Fig. 1. Comparison of all CEA values of plasma pools 1-4. Duplicates differing by more than $5 \%$ from single values have been omitted.

C = columns

D $=$ dialysis

Bar $=$ arithmetic mean

\section{Statistical analysis}

For the calculation of the regression lines in figures 2 and 3 , a structural relationship model (6) was applied: a linear response for each method was assumed, where both sets of measurements include errors. The corresponding correlation coefficients give a measure of the linear regression. Furthermore, the observed inhomogeneity of the variance was taken into account.

\section{Results}

Laboratory 2 performed the ultrafiltration method, the others the dialysis procedure. According to our protocol, we excluded CEA values, where mean and single counts/ min values of duplicates differed by more than $5 \%$ in

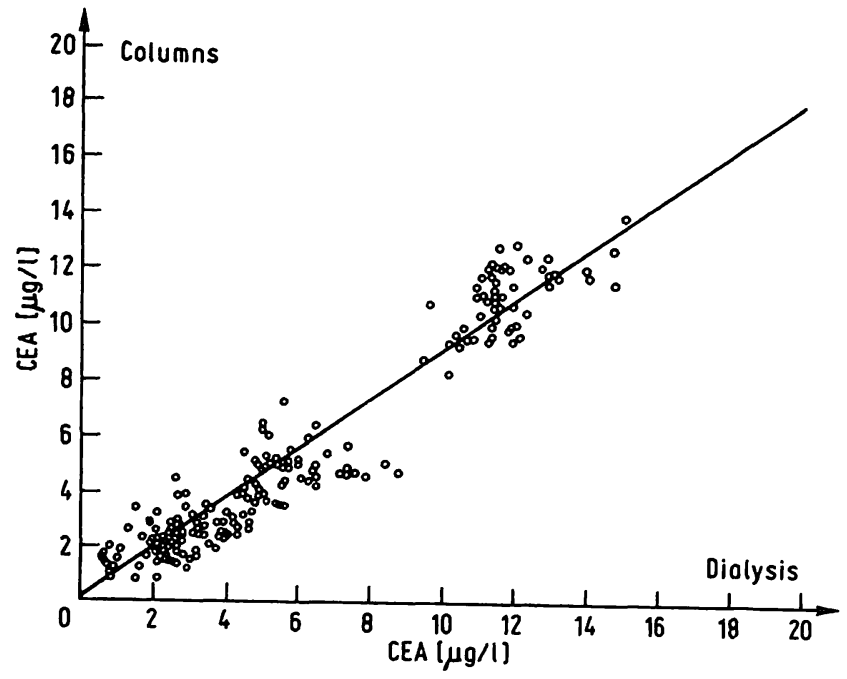

Fig. 2. Correlation of CEA results of plasma pools 1 to 4 for columns and dialysis procedures. Duplicates differing by more than $5 \%$ from single values have been omitted. Calculated regression line: $y=a+b$

$$
\begin{aligned}
& \mathrm{a}=0.15 \pm 0.09 \\
& \mathrm{~b}=0.9 \pm 0.02 \\
& \mathrm{n}=214
\end{aligned}
$$

Correlation coefficient: $\quad \mathrm{r}=0.965$

the following figures and tables. The dialysis results for week 2 and week 3 for one laboratory (No. 4) and column results for week 1 for laboratory No. 4 were also omitted due to a systematic error in the dialysis procedure, and due to an outdated batch of columns which laboratory No. 4 received in week 1.

A survey of the results of all laboratories for the 4 different plasma pools are given in figures 1 and 2 . As calculated from figure 2 the correlation coefficient was 0.96 for comparison of the column technique with the dialysis or ultrafiltration procedure. The mean CEA plasma values calculated from the results of all laboratories show slightly higher CEA levels for dialysis compared to column techniques (tab. 1).

\begin{tabular}{|c|c|c|c|c|c|c|c|c|c|c|c|c|c|c|}
\hline & \multicolumn{2}{|c|}{ Laboratory 1} & \multicolumn{2}{|c|}{ Laboratory 2} & \multicolumn{2}{|c|}{ Laboratory 3} & \multicolumn{2}{|c|}{ Laboratory 4} & \multicolumn{2}{|c|}{ Laboratory 5} & \multicolumn{2}{|c|}{ Laboratory 6} & \multicolumn{2}{|c|}{ All laboratories } \\
\hline & $\mathrm{C}$ & D & C & D & C & D & C & D & C & D & $\mathrm{C}$ & D & $\mathrm{C}$ & D \\
\hline $\begin{array}{l}\text { CEA } \\
(\mu \mathrm{g} / 1) \text { Mean } \\
\text { Pool } 1\end{array}$ & $\begin{array}{l}2.00 \\
0.31\end{array}$ & $\begin{array}{l}2.69 \\
0.50\end{array}$ & $\begin{array}{l}1.53 \\
0.41\end{array}$ & $\begin{array}{l}0.88 \\
0.34\end{array}$ & $\begin{array}{l}1.94 \\
0.56\end{array}$ & $\begin{array}{l}2.01 \\
0.78\end{array}$ & $\begin{array}{l}1.52 \\
0.27\end{array}$ & $\begin{array}{l}1.88 \\
0.44\end{array}$ & $\begin{array}{l}1.22 \\
0.45\end{array}$ & $\begin{array}{l}1.59 \\
0.86\end{array}$ & $\begin{array}{l}2.32 \\
0.33\end{array}$ & $\begin{array}{l}2.23 \\
0.37\end{array}$ & $\begin{array}{l}1.77 \\
0.54\end{array}$ & $\begin{array}{l}1.88 \\
0.81\end{array}$ \\
\hline $\begin{array}{l}\text { CEA Mean } \\
(\mu g / 1) \text { S.D. } \\
\text { Pool } 2\end{array}$ & $\begin{array}{l}2.90 \\
0.32\end{array}$ & $\begin{array}{l}4.04 \\
0.45\end{array}$ & $\begin{array}{l}2.48 \\
0.53\end{array}$ & $\begin{array}{l}2.40 \\
0.29\end{array}$ & $\begin{array}{l}3.23 \\
0.68\end{array}$ & $\begin{array}{l}2.96 \\
1.01\end{array}$ & $\begin{array}{l}2.39 \\
0.20\end{array}$ & $\begin{array}{l}3.97 \\
0.23\end{array}$ & $\begin{array}{l}1.87 \\
0.71\end{array}$ & $\begin{array}{l}2.79 \\
0.77\end{array}$ & $\begin{array}{l}2.88 \\
0.50\end{array}$ & $\begin{array}{l}3.16 \\
0.46\end{array}$ & $\begin{array}{l}2.63 \\
0.68\end{array}$ & $\begin{array}{l}3.25 \\
0.83\end{array}$ \\
\hline $\begin{array}{l}\text { CEA Mean } \\
\text { (ug/1) M.D. } \\
\text { Pool } 3\end{array}$ & $\begin{array}{l}4.99 \\
0.61\end{array}$ & $\begin{array}{l}6.90 \\
1.01\end{array}$ & $\begin{array}{l}4.58 \\
0.57\end{array}$ & $\begin{array}{l}4.87 \\
0.45\end{array}$ & $\begin{array}{l}5.88 \\
0.76\end{array}$ & $\begin{array}{l}6.18 \\
1.26\end{array}$ & $\begin{array}{l}4.92 \\
0.22\end{array}$ & $\begin{array}{l}6.98 \\
0.60\end{array}$ & $\begin{array}{l}3.94 \\
0.31\end{array}$ & $\begin{array}{l}5.37 \\
0.65\end{array}$ & $\begin{array}{l}4.99 \\
0.51\end{array}$ & $\begin{array}{l}5.23 \\
0.45\end{array}$ & $\begin{array}{l}4.89 \\
0.79\end{array}$ & $\begin{array}{l}5.81 \\
1.09\end{array}$ \\
\hline $\begin{array}{l}\text { CEA } \\
(\mu \mathrm{g} / 1) \text { Mean } \\
\text { Pool } 4 \\
\text { S.D. }\end{array}$ & $\begin{array}{r}12.49 \\
0.81\end{array}$ & $\begin{array}{r}12.72 \\
1.38\end{array}$ & $\begin{array}{l}9.96 \\
1.15\end{array}$ & $\begin{array}{r}11.13 \\
1.03\end{array}$ & $\begin{array}{r}11.92 \\
0.44\end{array}$ & $\begin{array}{r}11.99 \\
0.95\end{array}$ & $\begin{array}{r}11.67 \\
0.31\end{array}$ & $\begin{array}{r}13.90 \\
0.58\end{array}$ & $\begin{array}{r}10.04 \\
0.47\end{array}$ & $\begin{array}{r}11.55 \\
0.63\end{array}$ & $\begin{array}{r}10.90 \\
1.05\end{array}$ & $\begin{array}{r}11.23 \\
0.71\end{array}$ & $\begin{array}{r}11.16 \\
1.23\end{array}$ & $\begin{array}{r}11.91 \\
1.23\end{array}$ \\
\hline
\end{tabular}

Tab. 1. Mean CEA values and standard deviations in $\mu \mathrm{g} / 1$ CEA of plasma pools 1 to 4 for columns (C) and dialysis (D) procedures, calculated from repeated CEA determinations over a period of 4 weeks. 
The correlation between the values of the 4 〈Roche〉 control specimens for columns and dialysis in all laboratories is given in figure 3 . The correlation coefficient was also 0.96 , which is comparable to the results obtained with the plasma pools.

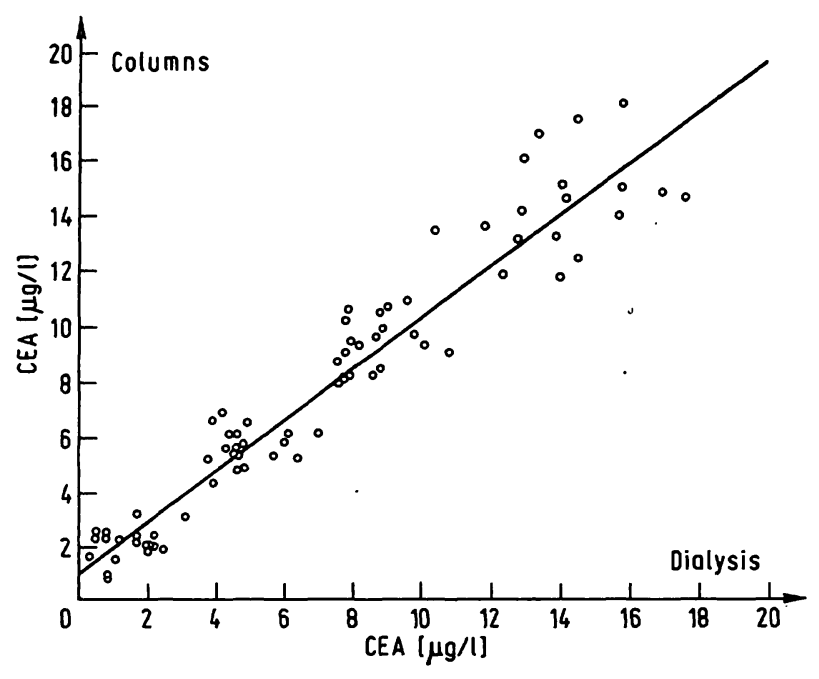

Fig. 3. Correlation of results of all control specimens for columns and dialysis procedures. Duplicates differing by more than $5 \%$ from single values have been omitted.

Calculated regression line: $y=a+b x$

$a=0.98 \pm 0.14$

$\mathrm{b}=0.98 \pm 0.03$

$\mathrm{n}=76$

Correlation coefficient: $\quad r=0.96$

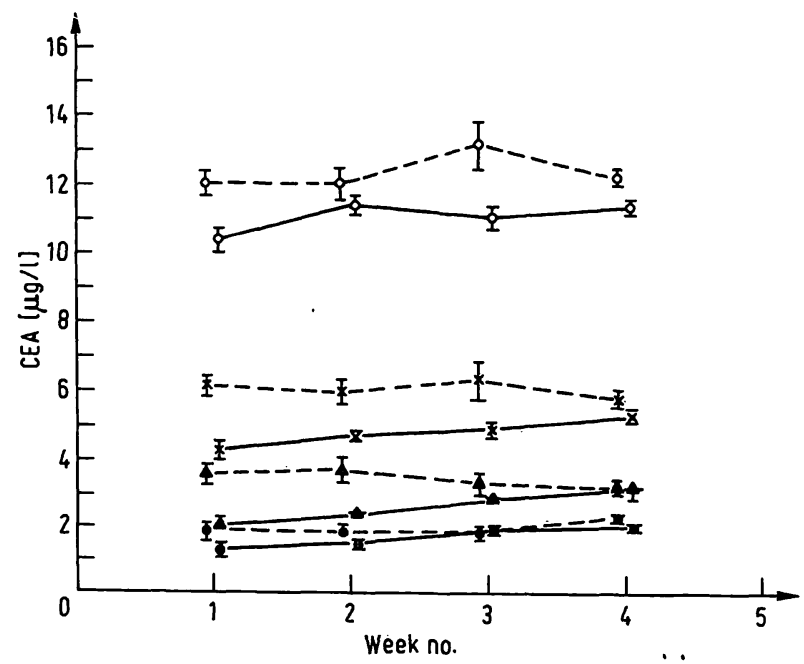

Fig. 4. Interassay variations of the mean values for plasma pools 1 to 4 during 4 weeks.

$\mathrm{Bar}=$ standard error of the mean

- - column result pool 1

-..- dialysis result pool 1

$\triangle$ - column result pool 2

A.-. dialysis result pool 2

$x$ - column result pool 3

$X$-.. dialysis result pool 3

- - column result pool 4

o... dialysis result pool 4
In table 1 the individual mean values of CEA $(\mu \mathrm{g} / 1)$ and standard deviations of the 4 different plasma pools tested over a period of 4 weeks are summarized. The standard deviations of all values of all laboratories calculated for pool 1 to 4 for columns and dialysis were: $0.54,0.68$, $0.79,1.23$, and $0.81,0.83,1.09,1.23$ respectively. For the column technique, pool 1 , they ranged from 0.27 to 0.56 , for pool 2 from 0.2 to 0.71 , for pool 3 from 0.22 to 0.76 , and for pool 4 from 0.31 to 1.15 . The corresponding ranges for the dialysis technique were: 0.34 to $0.86,0.23$ to $1.01,0.45$ to 1.26 , and 0.58 to 1.38 .

In figure 4 the week to week variations, calculated for all 4 plasma pools and all 4 weeks are depicted. No relevant trend became visible and the standard error of means was found to be smaller for column techniques. The low column values compared to those of the dialysis method are apparent.

In table 2 the variances for both methods are given. The variances depend on the region of the measured CEA values; they are therefore depicted for three typical regions of CEA, namely $2.0,5.0$, and $10.0 \mu \mathrm{g} / 1$. The experimental design allowed a direct comparison of the variance of measurement of both methods. In this table the standard deviation between replicates within the same laboratory, $\mathrm{SD}_{\text {Replicates, }}$, is given for different regions of CEA. It was found that for both methods the standard deviation increases with increasing values of CEA proportional to the square of the mean CEA concentration.

Tab. 2. Standard deviations of mean values within the same laboratory and between laboratories for concentration ranges of 2.5 , and $10 \mu \mathrm{g} / 1$.

$\mathrm{SD}_{\text {repl. }}=$ Standard deviations between replicates within the same laboratory and the same week.

$\mathrm{SD}_{\text {lab. }}$ = Standard deviations of mean for the same pool between laboratories.

\begin{tabular}{lcll}
\hline & $\begin{array}{c}\text { Region of } \\
\text { CEA }(\mu \mathrm{g} / \mathrm{l})\end{array}$ & Column & Dialysis \\
\hline SD $_{\text {Repl. }}$ & 2.0 & 0.42 & 0.52 \\
& 5.0 & 0.67 & 0.83 \\
& 10.0 & 0.94 & 1.17 \\
SD $_{\text {Lab. }}$ & 2.0 & 0.37 & 0.40 \\
& 5.0 & 0.59 & 0.63 \\
& 10.0 & 0.83 & 0.90
\end{tabular}

The fact that identical samples were measured in different laboratories made it possible to estimate the standard deviation of the mean values for the same pool between laboratories $\left(\mathrm{SD}_{\text {Laboratory }}\right)$. These estimates are also given in the table for different regions of CEA. 
The comparison of the mean values, calculated in the same laboratory for each week separately, allowed the estimation of the standard deviation between different weeks. These standard deviations were small compared with the standard deviation within the weeks ( $\left.S D_{\text {Replicates }}\right)$ for both methods. Therefore, they are not relevant and were not included in the table.

The percentage of measurements in which the difference of counts/min between the mean and single value of duplicates was greater than $5 \%$ were also evaluated for the 4 plasma pools: for column techniques we recorded $1.4 \%, 0 \%, 1.4 \%, 1.4 \%$, compared to $13.9 \%$, $20.8 \%, 12.5 \%$ and $9.7 \%$ for dialysis. These results again showed the higher accuracy of the column techniques when compared with the dialysis method.

\section{Discussion}

The present investigation provides an assessment of the reliability of a CEA determination performed with a widely distributed commercial CEA kit. The study also compared 3 different assay procedures, all recommended by the manufacturer for this radioimmunoassay. The reproducibility of the assay was found to be mainly dependent on the concentration of the CEA and the assay procedures used. The column technique showed the best reproducibility in all CEA concentration ranges tested and proved to be superior to dialysis or ultrafiltration techniques with respect to interassay variances. The precision level of the test as judged by the $5 \%$ deviation of duplicates was decreased to $2 \%$ when using the column technique, compared to about $15 \%$ with the other techniques. On average the CEA values determined by the column procedure were lower as compared to dialysis, probably due to a binding of CEA to column material rather than to systematic changes or deviations in the measurements. Therefore, it seems tó be safe to start with any one of these

\section{References}

1. Lo Gerfo, P., Krupey, J. \& Hansen, H. J. (1971) N. Engl. J. Med. 285, 138-141.

2. Egan, M. L., Lautenschleger, J. T., Coligan, J. E. \& Todd, C. W. (1972) Immunochem. 9, 289-299.

3. Laurence, D. J., Stevens, U., Bettelheim, R., Darcy, D. Leèese, C., Tuberville, C., Alexander, P., Johns, E. W.

\& Neville, A. M. (1979) Brit. Med. J. III, 605-609. methods, but the same method should be used during a follow up study.

As to the medical decision lcvel using column techniques, an increase of $75 \%$ (2 SD) in the CEA concentration range from 0 to $4 \mu \mathrm{g} / \mathrm{l}, 30 \%$ in the range of 4 to 8 $\mu \mathrm{g} / \mathrm{l}$ and $20 \%$ in the range of 8 to $12 \mu \mathrm{g} / 1$ is regarded as significant, and further control measurements must be performed in the follow up of such patients.

Our type of proficiency testing, carried out over a period of 4 weeks only, could also be used as a valuable quality control for the CEA (Roche) RIA test. A stock of patients' plasma collected from many individual patient plasmas could serve as a CEA standard for years. By using such standard plasma samples, even minimal changes of the assay due to new reagents or procedures could be detected and corrected, thus guaranteeing an optimal CEA follow up, which could serve as a basis for the clinical management of these patients.

The correct application of the CEA determination as shown in this laboratory investigation gave comparable CEA results in all laboratories, thus differing from a previous study (5). In this paper nearly $25 \%$ of the results reported did not belong to their original nominal groups. $16 \%$ of the participating laboratories were not in a position to detect differences between samples containing 1.1 or $5.5 \mu \mathrm{g} / 1$ of CEA. Only once did a determination of 5 plasma pools give between laboratory variances that were greater than the within laboratory variances, which - in our study - were found to lay in the same range. Finally it became obvious that the time saving column technique proved to have the best reproducibility when compared to procedures like dialysis or ultrafiltration, and therefore should be considered when CEA determination has to be introduced in a clinical laboratory.
4. Meriadec, B., Martin, F., Guerin, J., Henry, R. \& Klepping, C. (1973) Bull. Cancer 60, 403-410.

5. Taylor, R. N., Fulford, F. M. \& Huong, A. Y. (1977) J. Clin. Microbiol. S, 433-438.

6. Lindley, D. V. (1947) J. R. Statist. Soc., Suppl. 9, 218-244.

\section{Addresses of Authors}

Dr. H. Carmann, F. Hoffmann-La Roche \& Co. Ltd, Dept. Diagnostica, CH-4133 Schweizerhalle.

Dr. A. van Dalen, Bleuiand Ziekenhuis, Gouda, The Netherlands.

Dr. E. J:van Kampen, Diakonessenhuis, Groningen, The Netherlands.

Dr. H. Keogh, Bioscientia, D-6500 Mainz.

Dr. E. Lüdin, F. Hoff mann-La Roche \& Co. Ltd, EDP/Technical and Scient ific Systems Development, CH-4002 Basle.

Dr. H. Orjasaeter, Statens Institut for Folkehelsc, Immunologisk Avdeling, Oslo 1, Norway.

Dr. P. van der Ploeg, Diakonessenhuis, Groningen. The Netherlands.

Dr. H. J. Staab, Friedrich Miescher Laboratorium, Max Planck Gesellschaft, D-7400 Tübingen 
.
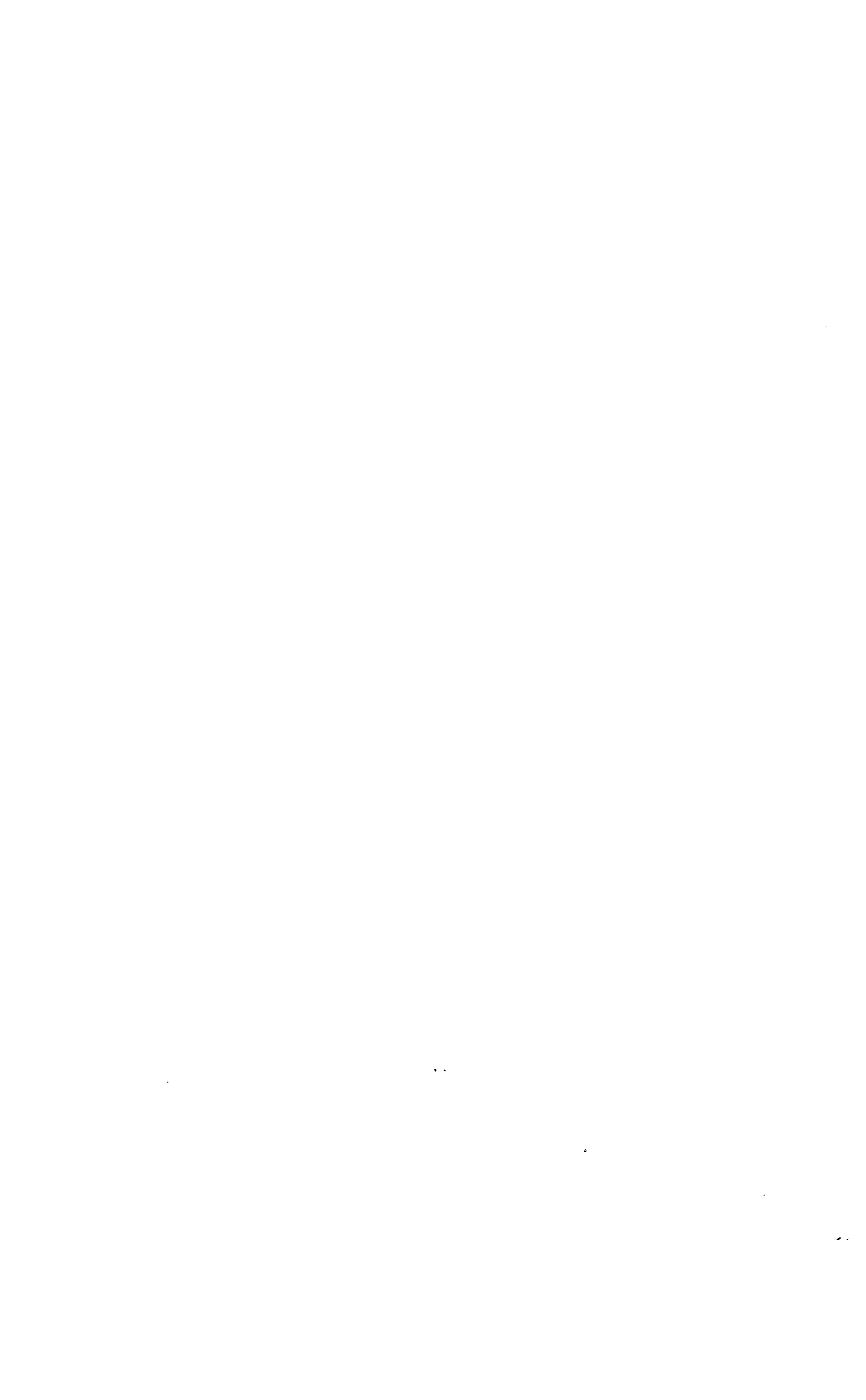

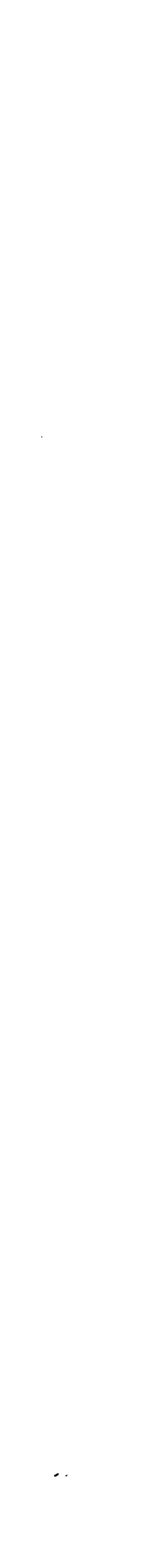

